\title{
Evidence Based Management for Learning: An Experiment
}

\author{
Samie Li Shang Ly and Raafat Saade \\ Concordia University, Montreal, Quebec, Canada \\ smie.vision@gmail.com raafat.saade@concordia.ca
}

\begin{abstract}
In this study we combine an immersive learning environment, an evidence based management method and the knowledge management SECI mindset to investigate students' learning from scientific journal articles. The study entailed the use of a web-based peer to peer system (P2PS) that, gives an identified subject matter, engages students in extracting knowledge from a source, processes that knowledge to create new knowledge, assesses each other's works, and then creates a test on the subject matter. We found that the immersive learning environment engaged students and improved their examination performance. However, comparing two groups, exposed versus not exposed to scientific journal article, both focused on keywords alone for the knowledge processing. This was not a desirable outcome from the knowledge management process and the tool. We believe this outcome is a result of engrained traditional learning and driven by our wish to make a change in educational practice, we propose our e-pedagogy methodology as a learning foundation for knowledge processing.
\end{abstract}

Keywords: Evidence Based Management, Immersive Learning, Information Technology, Learning Models, Educational Evolution

\section{Introduction \& Motivation}

The larger scope of this research revolves around the process that students need to learn how to formulate answerable questions (Ask), search for evidence (Acquire), critically appraise the evidence (Appraise), apply evidence to practice (Apply) and monitor their outcomes (Assess) as defined by Barends, and Briner (2014) - and which we will refer to herein as the peer to peer system, P2PS. Such foundational education, skills can develop to translate knowledge ready to use in collaboration through a network described by Quik et al. (2014) as "Collaboration has also been defined as a "process of participating in knowledge communities"..."in a coordinated, synchronous task to construct and maintain a shared conception of a problem". Ultimately, with acquired knowledge, used in collaboration, pro-

Material published as part of this publication, either on-line or in print, is copyrighted by the Informing Science Institute. Permission to make digital or paper copy of part or all of these works for personal or classroom use is granted without fee provided that the copies are not made or distributed for profit or commercial advantage AND that copies 1) bear this notice in full and 2) give the full citation on the first page. It is permissible to abstract these works so long as credit is given. To copy in all other cases or to republish or to post on a server or to redistribute to lists requires specific permission and payment of a fee. Contact Publisher@InformingScience.org to request redistribution permission. fessionals can make social changes such as solving complex social environments in poverty (Andersson, 2009). This method that usually exists in the workplace and contributes to the learning process of individuals on the job, can be reproduced in the classroom. It is in this pragmatic setting that we reproduce this process, and which was the object of the experiment presented herein. 
Within the context of this study, previous researchers have indirectly examined immersive learning methods, evidence based management, and Nonaka's SECI model in knowledge management. However, the integration of the three elements as a holistic set up for knowledge creation in an educational setting has not been investigated. We briefly provide the theoretical underpinnings of the aforementioned key elements of the learning process.

\section{The Setting: Immersive Learning}

Immersive Learning has evolved as a context setting of an atmosphere for learning that facilitates student interaction and engagement (Auster and Wylie, 2006). Student learning styles are no longer the same due to technology advances, classroom sizes, and educational curriculum. Consequently, pedagogical models have transformed from unidirectional teacher-to-student instruction to a dynamic IT based learning environment. In comparison to traditional passive learning styles, Inks and Avila (2008), show that active learning strategies are more effective. To explore the advantages of immersive learning, this environment ties together three learning styles such as experiential, constructivist, and collaborative.

Experiential learning is an environment and a context as defined by Barab and Duffy (2000). For example, students will understand cultural history by visiting a country, or visiting a mountain, a lake to examine its microscopic ecosystem. Although these activities are not available in regular classroom setting, technology can allow education to create environments that enhances human senses in order to make experiences more enjoyable, and memorable (Karns, 2005).

Constructivist learning takes into consideration the process of active knowledge construction to emphasizes on a student's prior knowledge and focus on challenging the student with their existing misconceptions of a subject matter (Von Glasersfeld, 1993; Wandersee et al., 1994;

Fernandes et al., 2003).

Collaborative or social learning consist of creating student interactions within a group where students share one another's resources and skills. As technological advancement today allows international communications, an increasing trend of interactive global learning is presented.

\section{The Technique: Evidence Based Management}

Evidence Based Management (EBM) has been studied to understand the practicality of education in Management sciences as authors Trank (2015), Minzberg (2004), Charlier, Brown and Rynes (2011) have observed a gap between academic researchers and industry practioners. EBM becomes important as a learning theory, and methods attempt to move professional decisions away from practioners' personal preference and often un-systematic experience but towards scientific evidence (Rousseau, 2006). EBM has been observed within different educational settings, however, little has been shown on how effective and how much do students understand when using academic research in practice.

In an investigation of MBA Classes, Charlier, Brown and Rynes (2011), they found 25\% of MBA courses from their study uses EBM in some form, however the implementation of such a method requests the instructor to understand academic information and usually are Ph.D holders. Quoted by L.Burke and Rau (2010) "Strengthening the teaching-research nexus holds vast potential to deliver not only the skills need to understand research to generations of upcoming managers, but also to instill values that recognize the validity of research."

Briner et al., (2009) explains the practice of EBM is making decisions through careful study of information from 4 sources such as the practioner's expertise and judgment, evidence within the local context, the critical evaluation of research evidence and the stakeholders (Walshe, 2014). Briner and Walshe, 2014 stresse the importance of overview available evidence which at times 
may be a wide range of contradictory evidence before making a balanced decision. Moreover, they believe the technique of doing systematic reviews not only applies to academics but also should be taught to practioners.

Despite its advantages, there are many obstacles in bridging the gap between practioners and academics because they occupy separate worlds (Rynes, Giluk and Brown, 2007). Difference can be the language usage, the researcher's conscientiousness to provide information functional to practioners, and the conflicts about what counts as effectiveness (Trank, 2015). Both academics and practioners share different values in the use of research evidence, academic focus on publications while practioners focus on the usage of information for a specific context that may change from one to another.

Hence, the role of academics, educators, and practionersare important. All three play an essential part to supporting the practice of EBM. The development of distinctive knowledge and skills depends on what isfound in each of these communities(Briner et al., 2009)).

Ultimately, research evidence found, collected by academicsis used by practioners, therefore scholars could put themselves in the mindset of transferring knowl edge to organizations, government policy (Kaplan, 2008), the performance of firms(Stefan, A., \& Paul, L., 2008). As for practioners, they need to acquire, assess, adapt and apply research evidence to their decision.

\section{The Philosophy: Nonaka's Knowledge Management}

Nonaka et al. (1996) introduced the SECI Model of knowledge creation as an important foundation of knowledge creation and knowledge transfer. Many researchers since then have looked into organizations and their knowledge management such as Zorgios, et al., (2009) in the software development process, Richtnér et al., (2014) in New Product Development, and Andreeva, T., \& Ikhilchik, I. (2011) in a cultural context. Although widely researched in organizations, we implemented it at the university level and adapted its context from professional training. The SECI model shows the transformation of tacit knowledge that is passed on through practice, guidance, imitation and observation in an environment of collaborative setting. Then through externalization by documenting information, to be combined into creating new knowledge that is finally learnt and internalize with practice of explicit knowledge.

Building our experiment based on Immersive learning with a focus on experiential environments where students can do hands on activities to serve as a more enjoyable experience than tradition book and reading learning, we also created an environment taking the students' learning speed and prior knowledge into account and finally to allow them to help each other through collaboration. Hence, the Peer to Peer learning management system was developed and used with that in mind.

\section{The Peer to Peer System}

After teaching undergraduate level classes for 3 years, we came to a realization that students need engagement in their studies in order to explore their critical thinking, and analytical skills. Lectures have become ineffective, especially as number of students enrolled in classrooms continue to increase every year. The advantage is the accessibility to information technology advances that allow us to create programs foster students' learning via collaborative work.

During one of my statistics class, we observed that students fail to engage with the classroom, even though the class was taught with the most innovative methods such as animated videos explaining theories and exercises. As a result, I cancelled the lecture and allowed students to work together in creating their own quiz questions. Surprisingly, students did not only engage in their course material, but also found the motivation to ask creative, critical questions. They also were 
engaged in teaching their peers how they came up with these questions. In a discussion with Professor Raafat Saade, he mentioned he also went through the same experience and created a program imitating this process on a learning management system. This program is called the Peer to Peer Interactive learning system.

The Peer to Peer Learning System is a specialized knowledge creation web based application. There are 3 phases to the process that highly engages students. In phase 1, students are asked to read a source of a subject matter (internet, document, notes, articles, figure, etc...), and were asked to create a number of questions. In phase 2, students are then required to rate their peer's questions by level of difficulty and quality. In phase 3, the moderator will select the top quality and selected difficulty sets of questions and allow students to take a quiz.

This program will serve as a basis to our study as it provides experiential, constructivist and collaborative immersive learning elements and will allow us to take a step further to introduce course material using EBM methods and observe knowledge creation. The purpose in this research are two-fold: First, to evaluate the usefulness of immersive learning using a Peer to Peer System (P2PS), and Second to combine academic readings and real life cases as an enhancement to EBM practice in classrooms while using this tool.

\section{Hypotheses}

There are two main questions we would like to explore, first the performance of students in immersive studying environments and traditional studying environment, second, the usage of research evidence in the context of undergraduate university level studies in business disciplines.

Hypothesis 1: Students who learn in an immersive environment perform better than students who use passive learning methods. (Immersive vs. traditional)

Hypothesis 2: Students utilize research evidence provided to them in their studies.

\section{Methodology}

Table 1 presents the research design to evaluate the two hypotheses. The experiment included two parts. The first used theory to start the P2PS process while the second utilized theory and evidence as well. In the first part, we compared the group that used the P2PS with that of a traditional approach. The goal here was to assess the generated knowledge (in this case, a test) and the reaction of the students to that test.

Sample and Data Collection: A sample of $1^{\text {st }}$ year and $2^{\text {nd }}$ year University students was chosen. $1^{\text {st }}$ year students enrolled in BTM 200 a business technology management introductory course, and $2^{\text {nd }}$ year students are enrolled in COMM 226 a Management Information Systems introductory course. All students were randomly assigned into groups to be part of Group A or Group B.

Sample representativeness: In the context of this research question, the undergraduate level in business studies are representative of future leaders and learning styles which will be applied in industry work.

Group A (Immersive) students were given a set of readings on project management theories and research evidence in the style of academic journals. Students were guided by the researcher through a trial of the P2PS, followed by 1 hour 30 minutes of reading and question creation. They were asked to create 5 multiple choice questions with 4 answer choices of varying level of difficulty and high quality.

In the assessment stage of the P2PS, multiple raters graded each question to ensure inter-rater reliability of each question. Questions were shown, however the answers were hidden to avoid students memorizing. Afterwards, students were given 15-20 minutes to evaluate 30 questions 
created from their peers, after a 10 minutes break, students were given 25 minutes to attempt a 15 multiple choices exam.

Table 1: Research Design to evaluate Hypothesis 1 and 2

\begin{tabular}{|c|c|c|}
\hline & Group A1- Immersive & Group B- Traditional \\
\hline $\begin{array}{c}\text { Part I - Theory } \\
\text { Students will be given the- } \\
\text { ory only reading material } \\
\text { based on academic journals. }\end{array}$ & $\begin{array}{l}\text { Group A will go through } \\
\text { the P2P learning process from } \\
\text { phase } 1 \text { to } 3 \text { (such as question } \\
\text { creation, question evaluation } \\
\text { and examination based on the } \\
\text { readings) }\end{array}$ & \multirow{3}{*}{$\begin{array}{l}\text { Group B will only perform } \\
\text { the examination stage of the } \\
\text { P2P program. } \\
\text { The examination taken by } \\
\text { these students were generat- } \\
\text { ed by students in Group A1 } \\
\text { and A2. }\end{array}$} \\
\hline & Group A2- Immersive & \\
\hline $\begin{array}{l}\text { Part II - Theory + Evi- } \\
\text { dence } \\
\text { Students will be given the- } \\
\text { ory and data reading material } \\
\text { based on academic journals }\end{array}$ & $\begin{array}{l}\text { Group A will go through } \\
\text { the P2PS learning process } \\
\text { from phase } 1 \text { to } 3 \text { (such as } \\
\text { question creation, question } \\
\text { evaluation and examination } \\
\text { based on the readings) }\end{array}$ & \\
\hline
\end{tabular}

Group B (traditional) students were given the same set of readings as Group A with theory and evidence. Students were guided into a quiet study room and given 1hour to 1 hour 30 minutes to work on the course material. When ready, they were given 25 minutes to attempt a traditional printed exam of 15 multiple-choice questions.

At the completion of the activity, students were granted $2 \%$ bonus marks in their respective university course. Hypotheses 1 and 2 will allow us to discriminate between traditional passive learning and immersive learning, as well as EBM elements of students' studying methods.

\section{Results and Discussion}

\section{Results for Hypothesis 1}

Hypothesis 1: Students who learn in an immersive environment perform better than students who use passive learning methods. (Immersive vs. traditional)

In order to test Hypothesis 1, we used an ANCOVA test to overview the difference in score between Immersive and Traditional Groups (A: Immersive coded 1, B: Traditional coded 2). The total sample consisted of 25 students in Immersive condition and 43 students in Traditional learning condition. See Table 2 for brief descriptive statistics. 
Table 2: Descriptive statistics.

Between-Subjects
Factors
\begin{tabular}{|ll|r|}
\hline & \multicolumn{1}{|c|}{ N } \\
\hline group & 1 & 25 \\
& 2 & 43 \\
\hline
\end{tabular}

Descriptive Statistics

Dependent Variable: grades

\begin{tabular}{|l|c|c|r|}
\hline group & Mean & $\begin{array}{c}\text { Std. } \\
\text { Deviation }\end{array}$ & N \\
\hline 1 & 9.6500 & 2.50416 & 25 \\
2 & 8.0233 & 2.44451 & 43 \\
Total & 8.6213 & 2.57227 & 68 \\
\hline
\end{tabular}

\section{Statistical Analysis - ANCOVA Test on Group A (Immersive) and Group B (Traditional)}

The Immersive condition scored higher than the Traditional condition taking into account the difficulty of each multiple-choice question. Moreover, the Levene's test showed that both variances in Group A and B are similar. See Table 3.

Table 3: Levene's test, variance check.

Levene's Test of Equality of Error
Variances ${ }^{\text {a }}$
Dependent Variable: grades
\begin{tabular}{|c|c|c|c|}
\hline F & df1 & df 2 & Sig. \\
\hline .000 & 1 & 66 & .984 \\
\hline
\end{tabular}

Tests the null hypothesis that the error

variance of the dependent variable is equal across groups.

a. Design: Intercept + avgdifficulty + group

Using an ANCOVA test, we took into consideration the average difficulty of each test as the difficulty level of each section varied (See the Appendix for an example of the P2P System). It has been found that the model is significant and there is a difference between the Immersive and the Traditional learning groups. See Table 4.

\section{Table 4: ANCOVA Test between Immersive (Group A) and Traditional (Group B) learning methods}

Tests of Between-Subjects Effects

Dependent Variable: grades
\begin{tabular}{|l|r|r|r|r|r|}
\hline Source & $\begin{array}{c}\text { Type III Sum } \\
\text { of Squares }\end{array}$ & df & Mean Square & \multicolumn{1}{c|}{ F } & \multicolumn{1}{c|}{ Sig. } \\
\hline Corrected Model & $43.131^{\mathrm{a}}$ & 2 & 21.566 & 3.503 & .036 \\
Intercept & 13.314 & 1 & 13.314 & 2.163 & .146 \\
avgdifficulty & 1.297 & 1 & 1.297 & .211 & .648 \\
group & 42.781 & 1 & 42.781 & 6.949 & .010 \\
Error & 400.180 & 65 & 6.157 & & \\
Total & 5497.563 & 68 & & & \\
Corrected Total & 443.312 & 67 & & & \\
\hline
\end{tabular}

a. R Squared $=.097$ (Adjusted R Squared $=.070$ ) 
Therefore we can conclude for this section that Immersive environment allow students to have higher performance in their tests in comparison to tradition conditions. Immersive students also find it easier while the test is fair for traditional test takers. Interestingly, the generated exams by the P2PS has more fluctuation in answer choices for mid proficiency students in tradition conditions while this fluctuation decreases for immersive students as their proficiency increases. The exams are also more powerful to discrimination students who are in low to mid proficiency for tradition conditions while the exam is more powerful for mid to high proficiency for immersive conditions. Meaning the generated questions were of good enough quality to discriminate between the skills of students. As a result, Hypothesis 1 is rejected.

\section{Results for Hypothesis 2}

Hypothesis 2: Students utilize research evidence provided to them in their studies.

We observed learning methods of students and asked whether research evidence help students understand course material better, and whether such evidence is taken into account by students when they are studying. Taking an exploratory point of view, we conducted an analysis of the most common highlighted words in each text given by students.

In order to evaluate the use of EBM within theoretical course material, we asked all students to bring a highlighter and use it on the text.

Group A2 and Group B were given the same text with theory and data.

It was shown that Group A1 (Immersive with Theory Only) and Group A2 (Immersive with Theory and data), both highlighted similar points.

Group A2, completely omitted the data part of the text and solely worked as it there was no data. As seen on Figure 7. Group A were the Immersive groups as well as the exam creators, since Group A2 did not take into account the research evidence portion of the text, the exam did not have any questions reflecting the data.

Another observation are the highlighted sections of Group B, most participants also omitted the data section of the text. Although 4/37 did look at the data. See Figure 8.

In a selected sample of 37 students GROUP B (Traditional) who used highlighters, only 1 critically looked at the data values and observed an error within the course material. While 21 students fully omitted the data section even given enough time to study. See Table 5.

\begin{tabular}{|l|l|}
\hline \multicolumn{2}{|c|}{ Table 5. Group B results in highlighted text } \\
\hline Number of Students & GROUP B (Traditional) \\
\hline 1 & Critically looked at the data values \\
\hline 3 & Slightly looked at the data values \\
\hline 12 & Highlighted key sections, but did not look at the data \\
\hline 21 & Completely omitted the Data section \\
\hline 37 & Total students \\
\hline
\end{tabular}

The presence of evidence based management still needs improvement as students learning behaviors are still theoretical. They do not process their understanding by looking at data provided to them, instead they focus on keywords. 
Results from Students with Theory and Data, as test creators. Based on Figure 7, the compilation of highlighting marks of the test for test creators, all test creators omitted the data section and did not ask any questions based on data. This is indicative of the importance of research evidence for undergraduate studies proving that evidence based management may not be an effective method in lower level studies. As a result, Hypothesis 2 is not rejected.

We then asked students a few questions about their learning methods and their experience. As a result, from the feedback given by test creators, most students enjoyed creating questions as it helped them understand the material. They said it "allows them think critically and assimilate knowledge". However they feel that this program should be used only for certain classes and with oversight from the professor. It is a good way to study for an exam to come. When asked to create hard questions, they were challenged but found it rewarding. When asked "Has the program helped you understand material better?", all students said yes.

\section{Results from Group B Traditional Test Takers}

In a sample of 41 students, we asked them the following questions: How effective was your studying methods? Students preferred more interaction, more practice and more hands on experience. They do not like the fact that many university courses are based on memorization and suggested course should focus on understanding the material. Many using the traditional method did not feel confident about their results and mentioned their studying method was keyword based.

If we told you, your peers generated the examination written today during their study period, do you think their questions were relevant to the text? 40 said the questions were relevant, 1 said they were not relevant. How different are the questions compared to a University level quiz? Students found a good balance between straight-forward questions and abstract questions that require thinking and understanding of the material provided. Most found the level to be the same. See Table 5.

\section{Limitations}

One may argue that the students were not incentivized to perform at their best, however, this says a lot about how students learn on their own time, and it had to be performance based for the evaluation to count. In the realm of consulting, a lot of work is done without explicit reward, however it is the curiosity and the knowledge acquired from such exposure that creates a good advisor. Based on this experiment, we can see that students do not go beyond their comfort zone and this has to be changed. The emphasis in evidence based management is not well adapted in today's educational system since students look for keywords and expect quizzes to touch on them. As a reflection to practioners, much of their experience come from the curiosity to learn, hence allows them to be critical thinkers.

\section{Future Research}

In future studies combining Immersive learning, Evidence Based Management and Knowledge Management, we wish to look at higher level courses such as the MBA, MSc in Administration level as these students learnt to implement their knowledge into industry. We also wish to keep in mind knowledge creation in organization and observe how training programs are constructed within corporations.

\section{Conclusion}

We were able to confirm that Immersive Learning is an essential tool to engage students in their studies. Immersive learning motivates critical thinking as students were challenged to create 
harder questions. We also found that the generation of such questions is can be equivalent to university level courses given by professors. Although a caution should be said about the important role of the instructor to provide clear guidelines to students when experiencing immersive learning. Another finding is the systematic approach of learning through memorization and key words observed by undergraduate students. Although many mentioned they wish to understand the material, there becomes a vicious cycle of spotting keywords when learning and we believe this should be changed as we propose to view education in business as knowledge creation through the SECI model which will benefit future consultants and professionals in their careers.

\section{References}

Andersson, K. (2009). Motivational dilemmas in collaborative learning activities: The case of the Swedish International Development Cooperation Agency (SIDA). Public Administration and Development, 29(5), 341-351.

Andreeva, T., \& Ikhilchik, I. (2011). Applicability of the SECI model of knowledge creation in Russian cultural context: theoretical analysis. Knowledge and Process Management, 18(1), 56-66.

Auster, E. R., \& Wylie, K. K. (2006). Creating active learning in the classroom: A systematic approach. Journal of Management Education, 30(2), 333-353.

Barab, S. A., \& Duffy, T. (2000). From practice fields to communities of practice. Theoretical Foundations of Learning Environments, 1(1), 25-55.

Barends, E. G., \& Briner, R. B. (2014). Teaching evidence-based practice: lessons from the pioneers; An interview With Amanda Burls and Gordon Guyatt. Academy of Management Learning \& Education, 13(3), 476-483.

Briner, R. B., \& Walshe, N. D. (2014). From passively received wisdom to actively constructed knowledge: teaching systematic review skills as a foundation of evidence-based management. Academy of Management Learning \& Education, 13(3), 415-432.

Briner, R. B., Denyer, D., \& Rousseau, D. M. (2009). Evidence-based management: concept cleanup time? The Academy of Management Perspectives, 23(4), 19-32.

Burke, L. A., \& Rau, B. (2010). The research-teaching gap in management. Academy of Management Learning \& Education, 9(1), 132-143.

Charlier, S. D., Brown, K. G., \& Rynes, S. L. (2011). Teaching evidence-based management in MBA programs: What evidence is there? Academy of Management Learning \& Education, 10(2), 222-236.

Charlier, S. D., Brown, K. G., \& Rynes, S. L. (2011). Teaching evidence-based management in MBA programs: What evidence is there? Academy of Management Learning \& Education, 10(2), 222-236.

Driscoll, P.M. (2000). Psychology of learning for instruction. Massachusetts: Allyn \& Bacon.

Fernandes, K. J., Raja, V., \& Eyre, J. (2003). Cybersphere: The fully immersive spherical projection system. Communications of the ACM, 46(9), 141-146.

Inks, S. A.,\& Avila, R. A. (2008). Preparing the next generation of sales professionals through social, experiential, and immersive learning experiences. Journal for Advancement of Marketing Education, 13(4), 47-55. Retrieved from http://www.mmaglobal.org/publications/JAME/JAME-Issues/JAMEWinter-2008/JAMEWinter2008v.13p.47-55.pdf

Kaplan, S. N. (2008). Are US CEOs overpaid? The Academy of Management Perspectives, 22(2), 5-20.

Karns, G. L. (2005). An update of marketing student perceptions of learning activities: Structure, preferences, and effectiveness. Journal of marketing Education, 27(2), 163-171.

Mintzberg, H. (2004). Managers, not MBAs: A hard look at the soft practice of managing and management development. Berrett-Koehler Publishers. 
Nonaka, I., Toyama, R., \& Hirata, T. (2008). Managing flow: A process theory of the knowledge-based firm (Vol. 19). New York: Palgrave Macmillan.

Quik, W. H., Wright, N. J., Rashid, A., \& Herjanto, H. (2014). Collaborative networked learning in manufacturing. International Journal of Advanced Corporate Learning, 7(4).

Richtnér, A., Åhlström, P., \& Goffin, K. (2014). "Squeezing R\&D”: A study of organizational slack and knowledge creation in NPD, using the SECI model. Journal of Product Innovation Management, 31(6), 1268-1290.

Rousseau, D. M. (2006). Is there such a thing as "evidence-based management"? Academy of Management Review, 31(2), 256-269.

Rynes, S. L., Giluk, T. L., \& Brown, K. G. (2007). The very separate worlds of academic and practitioner periodicals in human resource management: Implications for evidence-based management. Academy of Management Journal, 50(5), 987-1008.

Stefan, A., \& Paul, L. (2008). Does it pay to be green? A systematic overview. The Academy of Management Perspectives, 22(4), 45-62.

Ştefan, L. (2012). Immersive collaborative environments for teaching and learning traditional design. Procedia - Social and Behavioral Sciences 51: 1056-60. doi:10.1016/j.sbspro.2012.08.287.

Trank, C. Q. (2014). "Reading” evidence-based management: The possibilities of interpretation. Academy of Management Learning \& Education, 13(3), 381-395.

Von Glasersfeld, E. (1993). Reflections on number and counting. The development of numerical competence: Animal and human models, 225-243.

Wandersee, J. H., Mintzes, J. J., \& Novak, J. D. (1994). Research on alternative conceptions in science. Handbook of Research on Science Teaching and Learning, 177, 210.

Zorgios, Y., Vlismas, O., \& Venieris, G. (2009). The SECI Model and the learning curve phenomenon. Proceedings of the European Conference on Intellectual Capital, 589-599. 


\section{APPENDIX - Sample view of P2P Learning system}

\begin{tabular}{|c|c|c|c|c|c|}
\hline$\square$ & Question & Quality & Difficulty & $\begin{array}{l}\text { Total } \\
\text { Ratings }\end{array}$ & \\
\hline$\checkmark$ & The project management approach gives the promise to & 100 & 100 & 1 & \\
\hline$\checkmark$ & $\begin{array}{l}\text { If the project management certification is beneficial to the staffs' individual knowledge, } \\
\text { which factor would be the most critical likelihood for a project to succeed? }\end{array}$ & 100 & 100 & 1 & \\
\hline$\checkmark$ & $\begin{array}{l}\text { What period Illustrates the supreme reign of the "Iron Triangle"(Cost, Time and Quality) } \\
\text { as the criterion of success? }\end{array}$ & 100 & 33.33 & 1 & \\
\hline$\downarrow$ & $\begin{array}{l}\text { What are key elements that made an individual more adept to successfully manage a } \\
\text { project? }\end{array}$ & 100 & 66.67 & 1 & \\
\hline$\downarrow$ & $\begin{array}{l}\text { Bill's first project with his company delivered what it promised, was finished on time, did } \\
\text { not exceed the predetermined budget and met the company's standards of quality. In } \\
\text { what tier would Bill's project be considered a success? }\end{array}$ & 100 & 66.67 & 2 & \\
\hline$\checkmark$ & What kind of project management certification is used within the UN? & 100 & 66.67 & 1 & \\
\hline$\checkmark$ & Which element is most important in delivering a successful project? & 100 & 66.67 & 2 & \\
\hline$\checkmark$ & $\begin{array}{l}\text { Which of the following factors can make the project management certification one of the } \\
\text { organisational competencies? }\end{array}$ & 100 & 66.67 & 4 & \\
\hline$\downarrow$ & $\begin{array}{l}\text { Bill has been elected as team leader for his company's next big project. He wants the } \\
\text { project to follow a framework that is clearly defined. This is his first time being project } \\
\text { leader so he wants to know how to design and supervise the project. What significant } \\
\text { project framework would Bill benefit from adhering to? }\end{array}$ & 91.67 & 83.33 & 4 & \\
\hline$\bullet$ & $\begin{array}{l}\text { use the term certification to denote mastery of these skills, experiences, and } \\
\text { knowledge. }\end{array}$ & 88.89 & 77.78 & 3 & \\
\hline$\checkmark$ & What is the difference between younger project managers and older project managers. & 88.89 & 88.89 & 3 & \\
\hline$\checkmark$ & $\begin{array}{l}\text { A company gives free time to their employee so they can work on personal project. If } \\
\text { the project is good, the company will give its support. Which primary view of project } \\
\text { management is the company adopting according to Shenhar and Dvir? }\end{array}$ & 83.33 & 83.33 & 2 & \\
\hline$\downarrow$ & $\begin{array}{l}\text { Romeo and Juliet clothing company decided to deliver } 200 \text { pieces of hand made winter } \\
\text { scarves and mittens via air to Montreal -based clothing store, named LOL. Romeo and } \\
\text { Juliet company will be charged extra } \$ 300.00 \text { if shipped via air, so the company } \\
\text { decided to deliver the products via shipping line called MY BOAT in order to meet their } \\
\text { budget. LOL received the products on time and was happy about the quality of the } \\
\text { products. The scenario belongs to which layer of success? }\end{array}$ & 77.78 & 88.89 & 3 & \\
\hline$\downarrow$ & $\begin{array}{l}\text { For a lazy students who only wants to submit his work on time and does not really care } \\
\text { about his grade, what would be his definition of success? }\end{array}$ & 66.67 & 83.33 & 2 & \\
\hline$\downarrow$ & $\begin{array}{l}\text { As the project management principle evolves, will it be in-line with the present } \\
\text { definition? }\end{array}$ & 66.67 & 83.33 & 2 & \\
\hline
\end{tabular}




\section{Biographies}

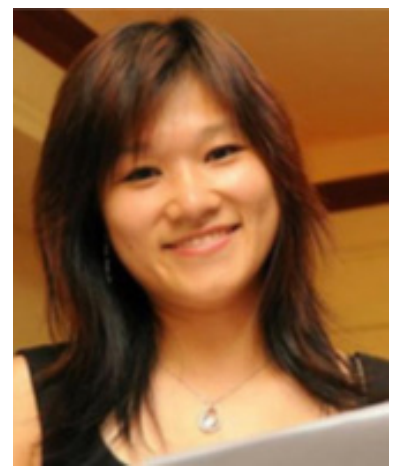

Samie Li Shang Ly is a Ph.D student in Business Technology Management at Concordia University, John Molson School of Business. She completed a Master Degree in Marketing from the same University. Samie previously has experience in Marketing Research and Business Intelligence. Her career goals are to continuously use the latest technologies to understand the business world.

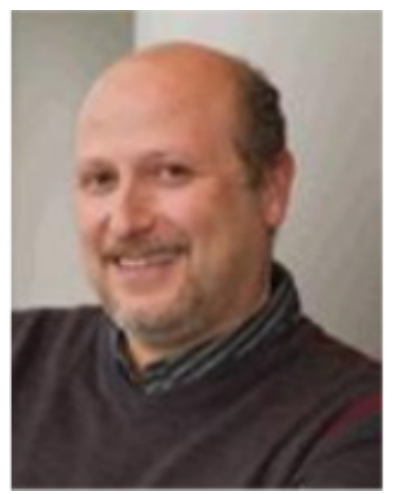

Dr. Raafat George Saadé has been teaching in JMSB since 1998. He obtained his $\mathrm{PhD}$ in 1995 (Concordia University) after which he received the Canadian National Research Council (NSERC) postdoctoral fellowship, which he completed at McGill University in Montreal. Dr. Saadé has extensive industry experience: research project manager, product developer and supply chain manager, operations manager, project leader, and information systems designer. Since 2000, he was also a consultant to the Canadian International Development Agency (CIDA) providing advice on international projects in Ukraine, Pakistan, and Slovenia. In the past 3 years, Dr. Saadé has been a senior advisor at the International Civil Aviation Organization (ICAO) providing input on strategic planning for organizational change. Dr. Saadé has published in top tier journals such as Information \& Management, Decision Sciences, Education and Computers, Decision Support Systems, Computers and Behavior, Journal of Information Technology in Education, and Expert Systems with Applications. 